\title{
Review on the Fundamental Usage of Bills of Quantities (BQ) by Contracting Organisations
}

Shamsulhadi Bin Bandi, Fadhlin Abdullah and Roslan Amiruddin, (University of Technology Malaysia, Malaysia)

\begin{abstract}
Detail literature review indicates a growing concern over the purpose of the $B Q$ to the practice and needs of contracting organisations. However, the number of studies dedicated to comprehensively review how $B Q$ is used by these organisations is limited. This review is conducted with the aim to identify the fundamental usage of $B Q$ to contracting organisations; especially within the parameter of a project period and management functions. The main three objectives are: (1) to comprehensively identify relevant literature concerning the usage of $B Q$ to contracting organisations, (2) to review the literature in order to identify the usage of $B Q$ to contracting organisations, and (3) to systematically synthesize the outcome of the review in order to identify the fundamental usage of $B Q$ to contracting organisations. Various literature findings are reviewed and validated to support the study's outcome. As a result, this study manage to identify thirty fundamental usage of $B Q$ arranged according to the parameter of interest. The significance of this study supports the evident usage of BQ by contracting organisations. It further enhances the current knowledge pertaining to its application in the industry and advancing further research pertaining on the application of $B Q$ in the construction industry.
\end{abstract}

Keywords: Bills of Quantities (BQ), Construction industry, Contracting organisations

\section{Introduction}

The construction industry works and operates on the basis of various forms of gathered information. The pool of vital information in any construction project is very important (Kwakye, 1997; Nourbakhsh et al., 2012). This input is regarded as the project's life-blood; which without critical tasks cannot be accomplished (Atkin, 1995). Critical information is also perceived as the enabler for coordination in the industry's fragmented environment (Atkin, 1995; Griffith et al., 2000; Kwakye, 1997; McDonagh, 1995; Winch, 2010). It essentially remains as the quintessence of the construction management (Winch, 2010). Additionally, valuable information also plays a major factor that contributes to the success of a project (Jaggar et al., 2001; Kwakye, 1997; Mohamed and Stewart, 2003). According to Ashworth and Hogg (2007); and Choy and Sidwell (1991); good information has a wider role to control the quality standard of a project. Evidently, the task of identifying the most appropriate form of information is of paramount importance for the purpose of increasing efficiency in the construction process.

Fundamentally, the construction industry generates a massive amount of information through its activity. For instance, according to Atkin (1995), a project worth £25 million is able produce some 150,000 drawings and another 6,000 site instructions. These and other forms of information are essentially created by the project team who consequently add value and pass information to each other until it reaches the phase for the project realization (Cornick and Mather, 1999). The information in a typical construction project may take numerous forms depending on its producers, project phase and the users of that particular information (Kwakye, 1997). Based on the intent and subsequent use of the information, these input can be structured and classified in either one or more classifications of commercial, technical, legal and managerial information (Atkin, 1995; Griffith, et al., 2000). 
As far as the construction industry is concern, the bills of quantities or BQs are wellrecognized as a form of information with widespread application in the industry. According to Davis et al. (2009) and Emmitt and Yeomans (2001), usually the BQ is composed by a quantity surveyor who will derived data from project drawings, schedule and specifications (Davis, et al., 2009; Emmitt and Yeomans, 2001; Khairuddin, 2011; Wood and Kenley, 2004) with the purpose of presenting the information in a format which facilitate the contractor's estimator to perform accurate pricing (Emmitt and Yeomans, 2001). Normally, the preparation of a $\mathrm{BQ}$ involves a detail analysis and interrogation of drawings and specification (Davis, et al., 2009) that will convey a thorough representation of the project information as a whole.

The modern norm and practice in tendering calls for the quantity surveyors to engage in client-sponsored BQ. However, historical development has witnessed the BQ evolve and advance from the practice of the builders (Holes, 1990; Wexler, 1986). According to Holes (1990); Jaggar, et al. (2001); Mohd Hisham and Azman (2008); Seeley and Winfield (1999), the $\mathrm{BQ}$ was historically sponsored by builders competing for the job. Hence, major development to the practice of producing $B Q s$ during this period is mainly builder-centric. It is driven by economic and business consideration without any intervention from the building owners sponsoring the construction work.

Regardless of this accord, towards the end of the $19^{\text {th }}$ century, recognition begins to grow on the part by building owners on the advantages of a $B Q$ tailor cut to suit their needs (Mohd Hisham and Azman, 2008). This has consequently resulted with the $B Q$ to be sponsored and produced by quantity surveyors who are engaged by the building owners to cover the widest range of cost advice and services. Subsequently, the change in the role of producing $B Q$ manage to reduce the undesirable incident of complotting alliance among competing builders (Lenard, 1991). This step further gives the building owner a sense of control over the financial aspect of their project while removing the problem of excessive claims as inherent in the earlier practice (Seeley and Winfield, 1999). The client-sponsored BQ has since become the practice of the construction industry and eventually become the standard of today's practice with the exception of the non-traditional system of construction procurement (Jaggar, et al., 2001; Seeley, 1997).

Consequent to this practice, the role change draws benefit to the client. For instance, the $B Q$ is increasingly customised to their requirements which command to the ease, in terms of its production and purposes (Turner, 1983). However, over the years, bounds have accumulated in the document and consequently, contractors are unable to relate the BQ with their usage requirements (Wood and Kenley, 2004). Evidently, concern over the limitation of the $B Q$ to serve the contractor's interest has invoked an alarming interest from contemporary literatures. For instance, Baccarini and Davis (2002), Wood and Kenley (2004), and more recently Hamimah et al. (2011), point out that this type of $B Q$ information is not adequate for contractor's utilization. While Morledge and Kings (2006) and Mohd Hisham and Azman (2008) conclude that this BQ is apparently inadequate for the purpose of a contractor's work planning and pricing. These are seemingly in line with a much earlier comment by Waterworth and Weddle (1978) and Benedict (1972) who criticize the value that this type of $\mathrm{BQ}$ provided to contractors. Jaggar, et al. (2001) remark it as the negative impact resulting from the client-sponsored $\mathrm{BQ}$ that diminish in terms of its utility to the contracting organisations.

Despite ongoing concern over the usefulness of the $B Q$ to the contracting organisations, the number of studies dedicated to comprehensively review how a $B Q$ is used by the organisations is found to be limited. This has prompt the vital question: what is supposed to be the function of the $\mathrm{BQ}$ to the contracting organisations and more importantly, how the outcome of such a comprehensive review can be used and expanded towards the interest that seeks to improve the utility of $\mathrm{BQ}$ to the organisations concerned. Accordingly, the questions have impelled a study to be carried out with an aim to identify the fundamental 
usages of the $B Q$. Emphasis is given to organise the identified use within the parameter of a project periods and management functions; which are apparent in the business of contracting organisations. The review presented in this paper is considered timely, judging from the continuous questions over its utility to the contracting organisations (Kwakye, 1997; Turner, 1983) and the unexpectedly limited attention given to this particular interest. In order to achieve the aim outlined in this study, three objectives are pursued: (1) to comprehensively identify relevant literature concerning the usage of the $B Q$ to the contracting organisations, (2) to review the literature in order to identify the usage of the $B Q$ to the contracting organisations, and (3) to systematically synthesize the outcome of the review in order to identify the fundamental usages of the $B Q$ to the contracting organisations. It further enhances the current knowledge pertaining to its application in the industry. It also contributes to the development of further research pertaining to the application of $B Q$ in the construction industry.

Accordingly, the paper is structured to provide a brief explanation on the methodology used. Next, the process involved to identify the relevant literature is reported. This is followed by the presentation of key outcomes arising from the review process. Following is a detail synthesis of the review before the study concludes with the potential of future interest in research concerning the $\mathrm{BQ}$. However, it should be noted that the review reported in this paper is an extension to the studies performed by the authors concerning the application and use of the $\mathrm{BQ}$ by contracting organisations in the construction industry. As such, extensive discussion concerning the $\mathrm{BQ}$ in general is not covered here but can be found elsewhere such as in Shamsulhadi (2011); Shamsulhadi and Fadhlin (2012a, 2012b, 2012c). Optimum focus is given in length towards the use of the $B Q$ in construction project which become the main thrust motivating the study.

\section{Methodology}

The review reported in this paper is essentially built upon two main approaches. Firstly, an extensive focus-based literature search is conducted on both printed and on-line materials with the purpose of identifying relevant studies concerning the usage of the $B Q$ by contracting organisations. Following this accomplishment, the literature are carefully reviewed and examined with the purpose of establishing a general observational aspects and proceeds with the allocation of appropriate merit concerning the content presented in the studies. Consequently, the process of an analytical evaluation is conducted which result in the fundamental usages of the BQ by the contracting organisations.

Secondly, in order to support the outcome derived from the review, a validation process is incorporated in the method. This step will ensure that the identified uses are seen as sufficient and reflect its actual usages for the contracting organisations. For this purpose, three industrial experts from three contracting organisations are invited to comment on the preliminary outcome. All comments received from the three separate interview sessions are recorded and moderated by an academic expert before improvements are introduced in the final outcome. Consequently, following these rigorous approaches, the fundamental uses of the $\mathrm{BQ}$ to the contracting organisations is proposed which succinctly developed from thorough consideration of relevant literature concerning the subject.

\section{The Use of the BQ in Construction Project}

The $B Q$ is highly advocated and fundamental in relation to the conventional or traditional process of building contracting (Jaggar, et al., 2001). The application of BQ helps to ensure maximum efficiency in the process of tendering. It is traditionally regarded as the best method of placing contract for building works (Seeley, 1997). According to Seeley (1997), as building operations increase in scale and complexity, it becomes seemingly impossible for contractor to price and subsequently compete for a job without substantial use of the $\mathrm{BQ}$. Hence, the $\mathrm{BQ}$ is an important and indispensable component in the practice of the contracting organisations. 


\begin{tabular}{|c|c|c|}
\hline No. & Use of $B Q$ & Source/Authors \\
\hline A & \multicolumn{2}{|l|}{ Procurement } \\
\hline A.1 & Tendering & $\begin{array}{l}\text { Ashworth and Hogg (2007); Blyth (2001); Davis, et al. (2009); } \\
\text { Hackett et al. (2007); Khairuddin (2011); Kirkham (2007); } \\
\text { Kodikara et al. (1993); Lee et al. (2011); Lenard (1991); Mohd } \\
\text { Hisham and Azman (2008); Morledge and Kings (2006); Rosli } \\
\text { et al. (2006, 2008); Seeley (1997); Sierra (1984a); Turner } \\
\text { (1983); Waterworth and Weddle (1978); Wilcox and Snape } \\
\text { (1980) }\end{array}$ \\
\hline A.2 & Sub-contractor procurement & Rosli, et al. (2006) \\
\hline A.3 & Material purchasing & Kodikara, et al. (1993) \\
\hline B & \multicolumn{2}{|l|}{ Communication } \\
\hline B.4 & $\begin{array}{l}\text { Medium to communicate design } \\
\text { information }\end{array}$ & $\begin{array}{l}\text { Fryer et al. (2004); Mohamed and Stewart (2003); Turner } \\
\text { (1983) }\end{array}$ \\
\hline C & \multicolumn{2}{|l|}{ Control } \\
\hline C.5 & Progress payment & $\begin{array}{l}\text { Ashworth and Hogg (2007); Davis, et al. (2009); Hughes } \\
\text { (1978); Kwakye (1997); Lee, et al. (2011); Lenard (1991); } \\
\text { Rosli, et al. (2006); Seeley (1997); Seeley and Winfield } \\
\text { (1999); Sierra (1984a); Turner (1983); Waterworth and } \\
\text { Weddle (1978) }\end{array}$ \\
\hline C.6 & Variation & $\begin{array}{l}\text { Ashworth and Hogg (2007); Davis, et al. (2009); Hughes } \\
\text { (1978); Khairuddin (2011); Kwakye (1997); Lee, et al. (2011); } \\
\text { Rosli, et al. (2006); Seeley (1997); Seeley and Winfield } \\
\text { (1999); Sierra (1984a); Turner (1983); Waterworth and } \\
\text { Weddle (1978) }\end{array}$ \\
\hline C.7 & Financial control and adjustment & $\begin{array}{l}\text { Davis, et al. (2009); Hughes (1978); Lenard (1991); Rosli, et } \\
\text { al. (2006): Sierra (1984a) }\end{array}$ \\
\hline C.8 & Final account & $\begin{array}{l}\text { Ashworth and Hogg (2007); Hughes (1978); Kwakye (1997); } \\
\text { Rosli, et al. (2006); Seeley and Winfield (1999); Turner (1983); } \\
\text { Waterworth and Weddle (1978) }\end{array}$ \\
\hline C.9 & Basis for price negotiation & Rosli, et al. (2006) \\
\hline C. 10 & Work supervision & Mohd Hisham and Azman (2008); Rosli, et al. (2006) \\
\hline C.11 & $\begin{array}{l}\text { Basis for report on work progress and } \\
\text { expenditure }\end{array}$ & $\begin{array}{l}\text { Ashworth and Hogg (2007); Khairuddin (2011); Rosli, et al. } \\
(2006,2008)\end{array}$ \\
\hline C.12 & $\begin{array}{l}\text { Part of contract documentation and } \\
\text { evidence for dispute resolution }\end{array}$ & Hughes (1978); Kwakye (1997); Sierra (1984a) \\
\hline C.13 & $\begin{array}{l}\text { Audit document for discrepancy } \\
\text { between drawings and specifications }\end{array}$ & Lenard (1991) \\
\hline C.14 & Reduce tendering risks & $\begin{array}{l}\text { Hughes (1978); Seeley (1997); Seeley and Winfield (1999); } \\
\text { Turner (1983) }\end{array}$ \\
\hline D & \multicolumn{2}{|r|}{ 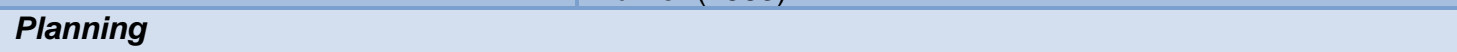 } \\
\hline D.15 & Resource planning & Rosli, et al. (2006); Seeley and Winfield (1999) \\
\hline D.16 & Work planning and programming & $\begin{array}{l}\text { Ashworth and Hogg (2007); Kwakye (1997); Lenard (1991); } \\
\text { Mohd Hisham and Azman (2008); Rosli, et al. (2006); Seeley } \\
\text { and Winfield (1999); Sierra (1984a) }\end{array}$ \\
\hline D.17 & Cash flow projection and budgetary & $\begin{array}{l}\text { Cattell et al. (2007); Mohd Hisham and Azman (2008); Rosli, } \\
\text { et al. (2006) }\end{array}$ \\
\hline D.18 & Schedule of labour requirements & Rosli, et al. (2006) \\
\hline D.19 & Cost planning & $\begin{array}{l}\text { Ashworth and Hogg (2007); Khairuddin (2011); Rosli, et al. } \\
\text { (2006) }\end{array}$ \\
\hline D.20 & $\begin{array}{l}\text { Basis for cost analysis and future } \\
\text { estimating }\end{array}$ & $\begin{array}{l}\text { AIQS (2001); Ashworth (2004); Khairuddin (2011); Lee, et al. } \\
\text { (2011); Seeley and Winfield (1999); Sierra (1984a) }\end{array}$ \\
\hline D.21 & Costing of alternative designs & Mohd Hisham and Azman (2008) \\
\hline D.22 & $\begin{array}{l}\text { Provide cost of maintenance for } \\
\text { completed building and data for asset } \\
\text { management }\end{array}$ & Davis, et al. (2009); Lenard (1991) \\
\hline D.23 & Material schedule preparation & $\begin{array}{l}\text { Ashworth and Hogg (2007); Mohd Hisham and Azman (2008); } \\
\text { Rosli, et al. (2006); Seeley and Winfield (1999) }\end{array}$ \\
\hline D.24 & Trade costing & Rosli, et al. $(2006,2008)$ \\
\hline
\end{tabular}

Table 1 The identified use of $B Q$ in construction project

Bin Bandi, S et al (2014) 'Review on the fundamental usage of Bills of Quantities (BQ) by contracting organisations', Australasian Journal of Construction Economics and Building, 14 (1) 118-131 
Generally as shown in Table 1, the use of the $B Q$ in a construction project can largely be categorised into four broad categories of procurement, communication, control and planning. These categories, which resulted from detail exploration of the literatures, are suggested by various authors from studies on the use of the $B Q$ in a construction project. Accordingly as shown in Table 1, most authors agreed that the $B Q$ has been primarily devised to be used for obtaining competitive tenders by contractors competing for jobs. Besides the traditional role in tendering (Davis, et al., 2009), the BQ is also important for the preparation of progress payment and assessment of variation orders. The importance of the $B Q$ in both activities have been specifically espoused by Davis and Baccarini (2004) in the findings of their study. According to the authors, extensive usage of the BQ in both tasks mentioned has concurred soundly with the literature covered by the authors and appears to be in line with the amount of literature covered for the purpose of this study (refer 'progress payment' and 'variation' in Table 1).

In addition to the categories of usage as shown in Table 1, the use of the $B Q$ in construction project could similarly be based on some specific project periods and its user in a construction project. Expressively, the $\mathrm{BQ}$ is used throughout the pre and post contract period of a construction project (Brook, 2008; Davis and Baccarini, 2004; Davis, et al., 2009; Odeyinka et al., 2009). In addition to these key stages, Skinner (1979) and Smith and Hoong (1985) has suggested 'tendering' and 'defect/final account' stage to respectively precede and succeed the key stages mentioned. Hence, it gives a strong indication that $B Q$ is evidently a practical document which is useful in all stages of a construction project.

In addition to the stages mentioned, $\mathrm{BQ}$ users have also received an equal attention from the literature as those are known to be the beneficiary from the use and application of the $B Q$ in a construction project. Generally, BQs are widely utilised and mainly useful to the clients, consultants and contractors as they have a stake and interest in an ongoing construction project (Rosli, et al., 2006; Sierra, 1984b). BQ utilisation during all these stages help a project to become more transparent through various functions as presented in Table 1. Despite the general agreement by the parties in a construction project who normally use the $B Q$, there is strong evidence from the literature which suggest a strong tendency to focus studies concerning the BQ on the contracting organization (see Davis and Baccarini (2004); Davis, et al. (2009); Kodikara (1990); Kodikara, et al. (1993); Skinner (1979, 1980); Smith and Hoong (1985) and Hamimah, et al. (2011)). This presumably rest with the common acceptance that the contracting organisations are the primary user of the BQ (Davis, et al., 2009; Wood and Kenley, 2004) either for the purpose of establishing the contract price during tendering (Jaggar, et al., 2001; Wilson et al., 1987) or later in the management of the construction work. Given these points, it is therefore imperative to conduct the review within the scope of the contracting organisations that are considered as the primary user of the document.

In relation to this paper, a review to identify the fundamental uses of the $B Q$ to the contracting organisations is an important component to improve the application of the $B Q$ to the organisations concerned. It rose from the necessity to understand how the BQ is used in every aspect or stages in the process of construction, particularly in those tasks directly involving the contracting organisations. By doing so, the contracting organisations' requirements towards the $B Q$ could be identified before any further research concerning the $B Q$ is to be instigated. Thus, the result of the study reported in this paper contains the prerequisite information which helps to map the association of the $B Q$ with the contracting organisations in an ongoing effort to improve the utility of the document in the construction industry. 


\section{Identifying the Use of the BQ by the Contracting Organisations}

\section{Literature Coverage and Aspect for Analytical Evaluation}

A thorough literature search has been conducted in both printed and electronic materials with an aim to identify previous studies concerning the use of the $\mathrm{BQ}$ by the contracting organisations. The object of this process is to build a complete source of up-to-date references which will be used to suggest the fundamental uses of the BQ envisioned in this study.

For the purpose of identifying the most relevant source of literature, Farrell (2011) has suggested 'references from references' as one of the best method in finding appropriate literature for research. Based on the method, early leads in the form of keywords are obtained from electronic searching and browsing, and are used for locating the next articles and materials concerning the topic of interest. The technique however, is a time consuming process which compelled an early preparation and structured methodological approach in its interpretation (Bryman, 2008).

As a result from the adopted method, eight publications as shown in Table 2 are identified and subsequently reviewed. Basically, the publications are selected as they covered the study interest, and discussed based on empirical works, the use of the $B Q$ to the organisations concerned. Hence, the selection has enabled detail examination on the use of $\mathrm{BQ}$ to be made across different studies and settings, which prompt for the formulation of the study's outcome.

\begin{tabular}{|c|c|c|c|c|}
\hline No. & Author/s & Year & Title of publication & Source \\
\hline 1. & Skinner & 1979 & $\begin{array}{l}\text { An analysis of the utility of bills } \\
\text { of quantities in the process of } \\
\text { building contracting }\end{array}$ & $\begin{array}{l}\text { Unpublished Ph.D. Thesis, } \\
\text { University of Aston in } \\
\text { Birmingham }\end{array}$ \\
\hline 2. & Skinner & 1980 & $\begin{array}{l}\text { The contractor's use of bills of } \\
\text { quantities }\end{array}$ & $\begin{array}{l}\text { ClOB Occasional Paper No. } 24 . \\
\text { Berkshire: Chartered Institute of } \\
\text { Building }\end{array}$ \\
\hline 3. & $\begin{array}{l}\text { Smith and } \\
\text { Hoong }\end{array}$ & 1985 & $\begin{array}{l}\text { Bills of quantities in Singapore - } \\
\text { A survey of their use and } \\
\text { application }\end{array}$ & $\begin{array}{l}\text { The Building Economist, 24(2), } \\
\text { 18-22 }\end{array}$ \\
\hline 4. & Kodikara & 1990 & $\begin{array}{l}\text { Data flow in building contractor } \\
\text { organisations }\end{array}$ & $\begin{array}{l}\text { Unpublished Ph.D. Thesis, } \\
\text { Loughborough University of } \\
\text { Technology }\end{array}$ \\
\hline 5. & $\begin{array}{l}\text { Kodikara, } \\
\text { Thorpe and } \\
\text { McCaffer }\end{array}$ & 1993 & $\begin{array}{l}\text { The use of bills of quantities in } \\
\text { building contractor } \\
\text { organisations }\end{array}$ & $\begin{array}{l}\text { Construction Management and } \\
\text { Economics, 11, 261-269 }\end{array}$ \\
\hline 6. & $\begin{array}{l}\text { Davis and } \\
\text { Baccarini }\end{array}$ & 2004 & $\begin{array}{l}\text { The use of bills of quantities in } \\
\text { construction projects - an } \\
\text { Australian survey }\end{array}$ & $\begin{array}{l}\text { Paper presented at the } \\
\text { International Construction } \\
\text { Research Conference of the } \\
\text { Royal Institution of Chartered } \\
\text { Surveyors (COBRA 2004), } \\
\text { Leeds Metropolitan University }\end{array}$ \\
\hline 7. & $\begin{array}{l}\text { Davis, Love and } \\
\text { Baccarini }\end{array}$ & 2009 & $\begin{array}{l}\text { Bills of quantities: nemesis or } \\
\text { nirvana }\end{array}$ & Structural Survey, 27(2), 99-108 \\
\hline 8. & $\begin{array}{l}\text { Hamimah, Abdul } \\
\text { Hadi, Siti } \\
\text { Maimunah, } \\
\text { Azizan and } \\
\text { Chong, H. Y. }\end{array}$ & 2011 & $\begin{array}{l}\text { Bills of quantities: perspectives } \\
\text { of contractors in Malaysia }\end{array}$ & $\begin{array}{l}\text { Australian Journal of Basic and } \\
\text { Applied Sciences, 5(11), 863- } \\
873\end{array}$ \\
\hline
\end{tabular}

Table 2 Detail of publications reviewed

In order to examine the content of the literature, a structured methodological approach is employed with the purpose of establishing the association of each study in relation to the 
others. Through these observations, the appropriate position for each study was determined thus enabling the identification of crucial information and allocation of appropriate merit pertaining to the use of the $\mathrm{BQ}$ to the contracting organisations.

With this intention in mind, the identified studies were examined following three observation aspects and sub-aspects of: (1) Category of studies - (1.1) Principal study or (1.2) Derivative study; (2) Approach to identify BQ usage - (2.1) Original or (2.2) Adaptational; (3) Parameter - (3.1) Management function and/or (3.2) Project period. Among all the observation aspects, parameter which involves project period and management function has been considered to carry one of this study great interest. By combining both parameters, the identified use of the $B Q$ could thoroughly be associated between where and when the $B Q$ is needed thus ensuring inclusiveness in the outcome proposed by this study.

Following the structured methodological approach employed, this study manages to determine the identified studies according to its appropriate observational aspects as shown in Table 3. In addition, studies produced by the same authors are combined to augment and coagulate the examination process. In relation to Table 3, studies done by Skinner (SK) and Kodikara (KD) are considered as principal studies as the studies originates from the author's own observations of the $\mathrm{BQ}$ usage. In addition, the approaches that have been taken in identifying the use of $B Q$ in both studies are considered original as both were devised to fulfil the research's primary objective. Aside from these two aspects and by comparison to Kodikara's, Skinner's study is considered as by far the most comprehensive due to the integration of both parameters of management function and project period. Accordingly, this has ensured the presence of both parameters as initially envisaged and closely resembles the environment which the $B Q$ is used in the contracting organisations.

\begin{tabular}{|c|c|c|c|c|c|c|c|c|}
\hline No. & $\begin{array}{l}\text { Observation } \\
\text { aspects }\end{array}$ & No. & $\begin{array}{l}\text { Observation sub- } \\
\text { aspects }\end{array}$ & $\mathbf{S K}^{*}$ & SH & KD* & DV $^{*}$ & HM \\
\hline \multirow[t]{2}{*}{1.} & \multirow[t]{2}{*}{ Category of studies } & 1.1 & Principal study & I & & l & & \\
\hline & & 1.2 & Derivative study & & 1 & & 1 & 1 \\
\hline \multirow[t]{2}{*}{2.} & \multirow{2}{*}{$\begin{array}{l}\text { Approach to } \\
\text { identify the use of } \\
\text { the } B Q\end{array}$} & 2.1 & Original approach & I & & l & & \\
\hline & & 2.2 & $\begin{array}{l}\text { Adaptational } \\
\text { approach }\end{array}$ & & l & & l & I \\
\hline \multirow[t]{2}{*}{3.} & \multirow[t]{2}{*}{ Parameters } & 3.1 & Management function & I & & l & & 1 \\
\hline & & 3.2 & $\begin{array}{l}\text { Project period (or } \\
\text { stage) }\end{array}$ & I & l & & & \\
\hline
\end{tabular}

Table 3 Observations from past studies on the use of BQ to contracting organisations

refer to combined studies. SK* = Skinner (1979, 1980); SH = Smith and Hoong (1985); KD* = Kodikara (1990), Kodikara, et al. (1993); $\mathrm{DV}^{*}=$ Davis and Baccarini (2004), Davis, et al. (2009); HM = Hamimah, et al. (2011)

The remaining three studies by Smith and Hoong (SH), Davis (DV) and Hamimah (HM) are original researche studies but comprise an adaptation of findings from either the principal studies or other studies not covered in detail here. For instance, the study by Smith and Hoong (1985) has adapted those findings by Skinner while Hamimah, et al. (2011) in essence had adapted Kodikara's findings in the study. An exception however was made for the study by Davis and Baccarini (2004) and Davis, et al. (2009) which has used various sources of literature in assessing the rank of the use of $B Q$ to the industry practitioners.

Notwithstanding the general evaluation, similar weight is given to studies considered principal or derivative for the purpose of achieving the aim envisioned in this paper. The decision is made to allow the element of comprehensiveness as apparent in the principal studies to be embedded in the study's outcome, while at the same time allowing the simplicity and suitability of the derivative studies to be adapted. Accordingly, the sections 
that follow explain the outcomes of the analytical process and decisions taken in respect of the formulation of the fundamental uses suggested in this study.

\section{The Process of Analytical Evaluation}

Following the aspects considered for the analytical evaluation and weight given to the literature, it is suggested that the findings by Skinner $(1979,1980)$ would be the most appropriate reference for the purpose of this study. This consideration was given based on the comprehensiveness of Skinner's work which covers both parameters required. However, there are concerns that the method used in the study has resulted in elaborate and complex findings on the use of the $B Q$ to the contracting organisations. Generally, Skinner has conducted his study in a single organization and the outcome of his work is mainly derived through active participation in the organization. Although in a way this has permitted the collection and subsequently presentation of rich data, it has nonetheless presents an excessively complex finding which would be unsuitable for the purpose of this review.

Thus, it is felt that although comprehensiveness is important, this quality will only be of secondary value if the complexity that is apparent in this work is not reduced. For this reason, the work by Smith and Hoong (1985) which adapted Skinner's finding is revisited for the purpose of finding feasible alternatives to this study. According to the work by Smith and Hoong (1985), the use of the BQ by the contracting organisations could be represented in twenty activities as shown in Table 4 . However, detail examination has revealed that the research only consider a single parameter (project period) while the other parameter (management function) are entirely omitted. Although it reduces the complexity observed in Skinner's work, the exclusion of management function parameter will consequently reduce the comprehensiveness of the $\mathrm{BQ}$ usage. In this instance, no association could be established between the use of the $\mathrm{BQ}$ and the management function which imperatively should be one of the important aspects leading to the study's outcome.

\begin{tabular}{|c|c|c|c|}
\hline No. & Parameter: Project period & No. & $\begin{array}{l}\text { Use of } B Q \text { by the contracting organisations - } \\
\text { represented in the following activities }\end{array}$ \\
\hline \multirow[t]{6}{*}{1.} & \multirow[t]{6}{*}{ Tender period } & 1.1 & Method statement \\
\hline & & 1.2 & Programme - pre-tender \\
\hline & & 1.3 & Material enquiries \\
\hline & & 1.4 & Tradesman quotes \\
\hline & & 1.5 & Sub-contractor's quotes \\
\hline & & 1.6 & Own price build-ups \\
\hline \multirow[t]{2}{*}{2.} & \multirow[t]{2}{*}{ Pre-contract period } & 2.1 & Programming of works \\
\hline & & 2.2 & Allocation of resources \\
\hline \multirow[t]{11}{*}{3.} & Construction period & 3.1 & Procurement of plant \\
\hline & & 3.2 & Ordering of materials \\
\hline & & 3.3 & Procurement of sub-contractors \\
\hline & & 3.4 & Off-site manufacture/delivery of components \\
\hline & & 3.5 & On-site manufacture of components \\
\hline & & 3.6 & On-site distribution of materials \\
\hline & & 3.7 & Stock control of materials \\
\hline & & 3.8 & Payment to sub-contractors \\
\hline & & 3.9 & Progress payment from client \\
\hline & & 3.10 & Claim - by contractor to client \\
\hline & & 3.11 & Claim - by sub-contractors to contractor \\
\hline 4. & Defects and final account period & 4.1 & Final account settlement \\
\hline
\end{tabular}

Table 4 The use of the $B Q$ by the contracting organisations by Smith and Hoong

Source: adapted from Smith and Hoong (1985, p. 20)

Bin Bandi, S et al (2014) 'Review on the fundamental usage of Bills of Quantities (BQ) by contracting organisations', Australasian Journal of Construction Economics and Building, 14 (1) 118-131 
Based on the abovementioned concern, it is decided that Kodikara (1990) and Kodikara, et al. (1993) work will be able to complement the requirement for the inclusion of the parameter omitted in the study by Smith and Hoong (1985). In relation to his work, Kodikara has suggested that the usage of the $B Q$ by the contracting organisations could be manifested in twenty-one management tasks arranged in five management functions shown in Table 5. In contrast with the study conducted by Smith and Hoong (1985), the work by Kodikara had clearly omitted the project period parameter. However, it is decided that by collating the two studies, the inclusiveness and feasibility of both principal and derivative study could finally be adduced. Based on this particular ground, the outcome proposed in this review is derived from these two studies which resulted in feasible and comprehensive uses of the BQ by the contracting organisations.

\begin{tabular}{|c|c|c|c|}
\hline No. & $\begin{array}{l}\text { Parameter: } \\
\text { Management functions }\end{array}$ & No. & $\begin{array}{l}\text { Usage of } B Q \text { by the contracting organisations - } \\
\text { represented in the following management tasks }\end{array}$ \\
\hline \multirow[t]{2}{*}{1.} & Estimating & 1.1 & Receiving quotations (rates and prices) from suppliers. \\
\hline & & 1.2 & $\begin{array}{l}\text { Receiving quotation from sub-contractors/pricing prime } \\
\text { cost items. }\end{array}$ \\
\hline \multirow[t]{6}{*}{2.} & \multirow[t]{6}{*}{ Purchasing } & 2.1 & $\begin{array}{l}\text { Identification of material required/to order from head } \\
\text { office. }\end{array}$ \\
\hline & & 2.2 & $\begin{array}{l}\text { Preparation of resource schedules for ordering } \\
\text { purposes. }\end{array}$ \\
\hline & & 2.3 & Reviewing material quotations from potential suppliers. \\
\hline & & 2.4 & Placing orders for resources. \\
\hline & & 2.5 & Purchasing/hiring/leasing plant and equipment. \\
\hline & & 2.6 & $\begin{array}{l}\text { Making arrangement with sub-contractors for their } \\
\text { work (time and amount required). }\end{array}$ \\
\hline \multirow[t]{5}{*}{3.} & \multirow[t]{5}{*}{ Planning } & 3.1 & $\begin{array}{l}\text { Identification of tasks and planning of construction } \\
\text { methods. }\end{array}$ \\
\hline & & 3.2 & Compilation of time based programme for work. \\
\hline & & 3.3 & $\begin{array}{l}\text { Incorporating the off-site manufacture items, special } \\
\text { resources etc. }\end{array}$ \\
\hline & & 3.4 & Incorporating preliminaries in the programme. \\
\hline & & 3.5 & $\begin{array}{l}\text { Incorporating the procurement of plant (hired-in) in the } \\
\text { programme. }\end{array}$ \\
\hline \multirow[t]{4}{*}{4.} & \multirow[t]{4}{*}{ Site management } & 4.1 & Assessment and allocation of materials for works. \\
\hline & & 4.2 & Assessment and allocation of plant for works. \\
\hline & & 4.3 & Assessment and allocation of labour for works. \\
\hline & & 4.4 & $\begin{array}{l}\text { Monitoring and recording actual use of resources and } \\
\text { sub-contractors work. }\end{array}$ \\
\hline \multirow[t]{4}{*}{5.} & \multirow{4}{*}{$\begin{array}{l}\text { Quantity } \\
\text { Surveying/Financial } \\
\text { control }\end{array}$} & 5.1 & Preparation of interim valuation for completed work. \\
\hline & & 5.2 & Preparing and monitoring cash flow. \\
\hline & & 5.3 & Accommodating variation to the works. \\
\hline & & 5.4 & Preparation of final bill. \\
\hline
\end{tabular}

Table 5: The usage of the BQ by the contracting organisations by Kodikara (1990) and Kodikara, et al. (1993)

Source: adapted from Kodikara (1990, p. 121) and Kodikara, et al. (1993, p. 265)

Bin Bandi, S et al (2014) 'Review on the fundamental usage of Bills of Quantities (BQ) by contracting organisations', Australasian Journal of Construction Economics and Building, 14 (1) 118-131 


\section{The Formulation and Validation of the Study's Outcome}

In order to achieve the aim of this paper, a decision is made to collate the study by Smith and Hoong (1985) with the study by Kodikara (1990) and Kodikara, et al. (1993). The main purpose is to integrate the distinct parameters of project period and management functions used in the studies. Correspondingly, the process involves critical examination of the study's outcomes and works by identifying any connections among points presented by the authors. Besides finding sensible connections, the step also involves skimming and trimming the findings by removing or combining any overlapping points identified from both studies. In essence, a preliminary outcome is successfully formulated by following the process involved in the review. The finding which is presented in Table 6, consist of thirty uses across the parameter of project period and management functions which represent the collation of studies considered for the purpose of this study.

Following the formulation of the uses, a validation is subsequently conducted as one of the important element to support the preliminary outcome. According to Lucko and Rojas (2010), one of the most effective ways to establish validity in a research outcome is through the involvement of domain experts, also known as subject matter experts. In relation to this study, validation is performed by inviting three experts from the contracting organisations who comments and deliberates the study's outcome. The sessions, which last at the expert's premises, are geared to identify any obscured meaning, overlapping, redundancies and shortcomings which would otherwise be apparent without such process. As the result of the validation, minor comments by the experts in terms of terminology used are recorded and commendable agreement in terms of its sufficiency is eventually accorded. During the final round, an academic expert is invited to moderate the comments made by the industrial experts followed by improvement and suggestion of the final outcome.

\section{The Fundamental Usage of the $\mathrm{BQ}$ by Contracting Organisations}

Pursuant to the comments made by the industrial experts, minor improvement in the form of terminology is incorporated and unanimously approved by an academic expert. The final outcome of the review which is shown in Table 6, consist of thirty items with each correspond to both parameters of project period and management functions.

By and large, the final outcome shown in Table 6 has successfully fulfils the aim of this study. It enables the individual usage of the $B Q$ to be arranged following the parameters of interest which thereupon permits deep understanding in terms of its perceived utility to be appreciated. Besides that, the process involved as described in the objectives are considered thorough and has placed a validation that is central in the process. Additionally, the outcome also contributes to the development of advancing further research pertaining on the application of $B Q$ in the construction industry.

Following the outcome formulated from the review, it is imperative to acknowledge that the $\mathrm{BQ}$ is in fact an important document in the day to day business of the contracting organisations. Its utility is shown to span across all four project periods and is utilised in all facet of the contracting organisations management functions. In a way, the formulation of the outcome has appropriately reaffirmed the position of the $B Q$ in the mainstream of the contracting business as an indispensable tool for management purposes. Hence, further studies which seek to expand and exploit the outcome presented in this review are considered timely and should become the main focus for advancing further knowledge concerning the $\mathrm{BQ}$. 


\begin{tabular}{|c|c|c|c|}
\hline & Project period & $\begin{array}{c}\text { Contracting } \\
\text { organisations } \\
\text { management } \\
\text { functions }\end{array}$ & The fundamental usage of the $B Q$ \\
\hline \multirow[t]{2}{*}{ A. } & \multirow[t]{2}{*}{ Tender period } & Estimating & $\begin{array}{l}\text { 1. Materials enquiries to supplier. Such as: materials' } \\
\text { detail, stock availability and method of assembly. } \\
\text { 2. Asking for materials quotations from suppliers. } \\
\text { 3. Asking for works quotations from sub-contractors } \\
\text { (work trade). } \\
\text { 4. Building up own price for work/items requested in the } \\
\text { BQ. }\end{array}$ \\
\hline & & Planning & $\begin{array}{l}\text { 1. Identification of task/activities and planning of } \\
\text { construction method. } \\
\text { 2. Programming the duration of task/activities for tender } \\
\text { pricing. } \\
\text { 3. Drafting method statement for the identified } \\
\text { task/activities. }\end{array}$ \\
\hline \multirow[t]{3}{*}{ B. } & \multirow[t]{3}{*}{$\begin{array}{l}\text { Pre-contract } \\
\text { period }\end{array}$} & Purchasing & $\begin{array}{l}\text { 1. Identification of material requirements to order from } \\
\text { suppliers. } \\
\text { 2. Preparation of material schedules for ordering } \\
\text { purposes. }\end{array}$ \\
\hline & & Planning & $\begin{array}{l}\text { 1. Preparation of detail work programme i.e. } \\
\text { establishing the relationship among task/activities. }\end{array}$ \\
\hline & & Site management & $\begin{array}{l}\text { 1. Planning for the allocation of materials for works. } \\
\text { 2. Planning for the allocation of plants/equipment for } \\
\text { works. } \\
\text { 3. Planning for the allocation of labour for works. }\end{array}$ \\
\hline \multirow[t]{4}{*}{ C. } & \multirow[t]{4}{*}{$\begin{array}{l}\text { Construction } \\
\text { period }\end{array}$} & Purchasing & $\begin{array}{l}\text { 1. Placing orders for materials to suppliers. } \\
\text { 2. Purchasing/leasing plants for works. } \\
\text { 3. Procurement of sub-contractors. } \\
\text { 4. Scheduling sub-contractor's work. } \\
\text { 5. Procurement of general labour. }\end{array}$ \\
\hline & & Planning & $\begin{array}{l}\text { 1. Off-site manufacturing of building components. } \\
\text { 2. On-site manufacturing of building components. }\end{array}$ \\
\hline & & Site management & $\begin{array}{l}\text { 1. Recording actual use of materials. } \\
\text { 2. Recording actual use of plants. } \\
\text { 3. Recording actual use of labours. }\end{array}$ \\
\hline & & $\begin{array}{l}\text { Quantity } \\
\text { Surveying/Financi } \\
\text { al control }\end{array}$ & $\begin{array}{l}\text { 1. Preparation of claim document for interim valuations. } \\
\text { 2. Preparation of claim document for varied works to } \\
\text { client (variation orders). } \\
\text { 3. Evaluation of claims submitted by sub-contractors } \\
\text { employed for the works. } \\
\text { 4. Preparation of payment to sub-contractors. } \\
\text { 5. Monitoring planned and actual project's expenditure. }\end{array}$ \\
\hline D. & $\begin{array}{l}\text { Defects and } \\
\text { final account } \\
\text { period }\end{array}$ & $\begin{array}{l}\text { Quantity } \\
\text { Surveying/Financi } \\
\text { al control }\end{array}$ & $\begin{array}{l}\text { 1. Preparation of final claim document to client. } \\
\text { 2. Preparation of document for closing of project's } \\
\text { account (final account). }\end{array}$ \\
\hline
\end{tabular}

Table 6: The fundamental usage of the $B Q$ by the contracting organisations - final outcome Source: adapted from the collation of studies by Smith and Hoong (1985, p. 20); Kodikara (1990, p. 121) and Kodikara, et al. (1993, p. 265)

\section{Conclusion}

The review presented in this paper is motivated by the lack of studies which focus on encapsulating the fundamental uses of the $B Q$ by the contracting organisations. Driven by this gap, an effort is initiated with an aim to identify the fundamental uses of the BQ by the contracting organisations which are identified as the primary users of the document. In order to achieve the aim outlined in this study, three objectives were proposed: (1) to comprehensively identify relevant literature concerning the use of the $B Q$ to the contracting 
organisations, (2) to review the literature in order to identify the use of the $B Q$ to the contracting organisations, and (3) to systematically synthesize the outcome of the review in order to identify the fundamental uses of the $\mathrm{BQ}$ to the contracting organisations. In accordance with the objectives of this study, thorough literature review is conducted and as a result, eight potential references were reviewed and systematically synthesized. Besides identifying the uses of the $B Q$ from literature, it also focus on collating the identified uses based on two important parameters of project period and management functions; both are considered as the central features of the outcome.

Following the outcome derived from the process of literature synthesizing, validation is run with the main purpose of ensuring the sufficiency of the proposed fundamental uses with the actual practice of the contracting organisations. For this purpose, experts from both the industrial and academic field are invited by way of close session. Vital critical comments are moderated for inclusion in the final outcome. Consequently, minor improvements are introduced and this result in thirty fundamental usage as shown in Table 6.

The outcome from this review however is limited for identifying the fundamental uses of the BQ. It is not specifically designed to answer issues beyond this scope. Nonetheless, the presented outcome is significance to build up understanding towards the BQ and acts as the catalyst to spur immediate attention on the subject.

\section{References}

AIQS. (2001) Guaranteed Bills of Quantities - discussion paper, 1 - 7.

Ashworth, A. (2004) Cost studies of building (4th Ed.). Essex: Pearson Prentice Hall.

Ashworth, A. and Hogg, K. (2007) Willis's practice and procedure for the quantity surveyor (12th Ed.). Oxford: Blackwell Publishing Ltd.

Atkin, B. (1995) 'Information management of construction projects', In P. Brandon \& M. Betts (Eds.), Integrated construction information. London: E \& FN Spon.

Baccarini, D. and Davis, P. (2002) 'Bills of Quantities - A Literature Review', The Building Economist, Sept.(2002), 10-16.

Benedict, J. (1972) 'The unpriceable items in Bills of Quantities, The Quantity Surveyor, 29 (2), 47-50.

Blyth, I. (2001) 'To Bill or Not to Bill', The Building Economist, June(2001), 4-12.

Brook, M. (2008) Estimating and tendering for construction work (4th ed.), Amsterdam: Elsevier Butterworth-Heinemann.

Bryman, A. (2008) Social research methods - 3rd ed, New York: Oxford University Press.

Cattell, D. W., Bowen, P. A. and Kaka, A. P. (2007) 'Review of unbalanced bidding models in construction', Journal of Construction Engineering and Management, 133 (8), 562 - 573.

Choy, W. K. and Sidwell, A. C. (1991) 'Bills of Quantities continued - Sources of variations in Australian construction contracts', Australian Construction Law Newsletter (21), 10-11.

Cornick, T. and Mather, J. (1999) Construction project teams - making them work profitably, London: Thomas Telford.

Davis, P. R. and Baccarini, D. (2004, 7-8 September 2004) 'The use of bills of quantities in construction projects - an Australian survey', Paper presented at the International Construction Research Conference of the Royal Institution of Chartered Surveyors (COBRA 2004), Leeds Metropolitan University, Leeds.

Davis, P. R., Love, P. E. D. and Baccarini, D. (2009) 'Bills of quantities: nemesis or nirvana', Structural Survey, 27 (2), 99-108.

Emmitt, S. and Yeomans, D. (2001) Specifying buildings - a design management perspective, Oxford: Butterworth-Heinemann. 
Farrell, P. (2011) Writing a built environment dissertation, Sussex: Wiley-Blackwell.

Fryer, B., Egbu, C., Ellis, R. and Gorse, C. (2004) The practice of construction management. Oxford: Blackwell Publishing.

Griffith, A., Stephenson, P. and Watson, P. (2000) Management system for construction. Essex: Pearson Education.

Hackett, M., Robinson, I. and Statham, G. (2007) The aqua group guide to procurement, tendering and contract administration, Oxford: Blackwell Publishing.

Hamimah, A., Abdul Hadi, M. N., Siti Maimunah, M. A., Azizan, S. and Chong, H. Y. (2011) 'Bills of Quantities: Perspectives of Contractors in Malaysia', Australian Journal of Basic and Applied Sciences, 5 (11), 863-873.

Holes, L. (1990) 'Finding an alternative', Chartered Quantity Surveyors (May 1990), 10-11.

Hughes, G. A. (1978) The Anatomy of Quantity Surveying, Lancaster, England: The Construction Press Ltd.

Jaggar, D., Ross, A., Love, P. E. D. and Smith, J. (2001) 'Overcoming information opacity in construction: A commentary', Logistics Information Management, 14 (5/6), 413 - 420.

Khairuddin. (2011) 'In need to assess the effectiveness of bills of quantities', Paper presented at the 10th Management in Construction Researchers (MiCRA) Conference (26 27 July 2011), International Islamic University Malaysia, Kuala Lumpur, Malaysia.

Kirkham, R. (2007) Ferry and Brandon's cost planning of building (8th Ed.). Oxford: Blackwell Publishing.

Kodikara, G. W. (1990) Data flow in building contractor organisations, Unpublished Ph.D Thesis, Loughborough University of Technology, Loughborough.

Kodikara, G. W., Thorpe, A. and McCaffer, R. (1993) 'The use of bills of quantities in building contractor organisations', Construction Management and Economics, 11, 261-269.

Kwakye, A. A. (1997) Construction Project Administration in Practice, Essex: Addison Wesley Longman Limited.

Lee, S., Trench, W. and Willis, A. (2011) Willis's elements of quantity surveying (11th Ed.), Sussex: Wiley-Blackwell.

Lenard, D. J. (1991) Cost efficiency in the building and construction industry. The Building Economist, 30 (2), 5-14.

Lucko, G. and Rojas, E. (2010) 'Research Validation: Challenges and Opportunities in the Construction Domain', Journal of Construction Engineering and Management, 136 (1), 127135.

McDonagh, N. H. (1995) 'Information systems research in construction - a foreword',In P. Brandon \& M. Betts (Eds.), Integrated construction information, London: E \& FN Spon.

Mohamed, S. and Stewart, R. A. (2003) 'An empirical investigation of users' perceptions of web-based communication on a construction project', Automation in Construction, 12 (1), 4353.

Mohd Hisham, A. and Azman, W. N. (2008) 'Bringing back the dead: Operationalizing the Bills of Quantitites', Paper presented at the International Conference for Project Management (18-20 November 2008), Universiti Malaya.

Morledge, R. and Kings, S. (2006) 'Bills of Quantities - A time for change?', Paper presented at the International Conference in the Built Environment in the 21st Century (ICiBE 2006), Mara University of Technology, Shah Alam.

Nourbakhsh, M., Rosli, M. Z., Irizarry, J., Zolfagharian, S. and Gheisari, M. (2012) 'Mobile application prototype for on-site information management in construction industry', Engineering, Construction and Architectural Management, 19 (5). 
Odeyinka, H., Kelly, S. and Perera, S. (2009) 'An evaluation of the budgetary reliability of bills of quantities in building procurement', Paper presented at the RICS Foundation Construction and Building Research Conference (COBRA 2009), University of Cape Town

Rosli, A. R., Muzani, M. and Siti Nurhuda, A. W. (2006) 'Bills of quantities - are they still useful and relevant today?', Paper presented at the International conference on construction industry (21 - 25 June 2006), Padang, Indonesia.

Rosli, A. R., Muzani, M. and Siti Nurhuda, A. W. (2008) 'Bills of Quantities - Are they still useful and relevant today?', The Building Economist, March, 16-23.

Seeley, I. H. (1997) Quantity Surveying Practice (2nd Ed.), London: Macmillan Press Ltd.

Seeley, I. H. and Winfield, R. (1999) Building quantities explained (5th Ed.), London: Macmillan and Co. Ltd.

Shamsulhadi, B. (2011) 'Bills of Quantities: Raison D'etre?' In K. Khalil (Ed.), Issues in Construction and Quantity Surveying, Kuala Lumpur: IIUM Press, 182-198

Shamsulhadi, B. and Fadhlin, A. (2012a) 'Conceptualizing issues relating to the bills of quantities', Paper presented at the ASEAN Post Graduate Seminar in the Built Environment, University Malaya.

Shamsulhadi, B. and Fadhlin, A. (2012b) 'Exploring issues on the usage of the bills of quantities and identifying relevant research area', Paper presented at the Management in Construction Research Association Postgraduate Conference, UTM Razak School of Engineering and Advanced Technology.

Shamsulhadi, B. and Fadhlin, A. (2012c, 7-10 July) 'Understanding the challenges in sustaining the bills of quantities in Malaysia', Paper presented at the 16th Pacific Association of Quantity Surveyors Congress (PAQS 2012), Bandar Seri Begawan Brunei.

Sierra, J. (1984a) 'Bills of Quantities - The roots of the quantity surveyor (Part 1)', The Building Economist, 22 (4), 379-380.

Sierra, J. (1984b) 'Bills of Quantities -The roots of the quantity surveyor (Part 2)', The Building Economist, 23 (1), 10.

Skinner, D. W. H. (1979) An analysis of the utility of Bills of Quantities in the process of building contracting, Unpublished Ph.D Thesis, University of Aston in Birmingham, Birmingham.

Skinner, D. W. H. (1980) 'The contractor's use of bills of quantities', CIOB Occasional Paper No. 24. Berkshire: Chartered Institute of Building.

Smith, J. and Hoong, W. K. (1985) 'Bills of Quantities in Singapore - A survey of their use and application', The Building Economist, 24 (2), 18-22.

Turner, D. F. (1983) Quantity Surveying - Practice and administration (3rd Ed.), New York: George Godwin.

Waterworth, H. W. and Weddle, A. E. (1978) 'Bills of Quantities for landscape works', The Quantity Surveyor, 35 (1), 244-245.

Wexler, H. E. (1986) 'Past, present and future of quantity surveying', The Building Economist, 24 (4), 2-5.

Wilcox, C. and Snape, J. A. (1980) Measurement of Construction Work (Second Edition), London: George Godwin Limited.

Wilson, O. D., Sharpe, K. and Kenley, R. (1987) 'Estimates given and tenders received: A comparison', Construction Management and Economics, 5, 211 - 226.

Winch, G. M. (2010) Managing construction projects - 2nd Ed. Sussex: Wiley-Blackwell.

Wood, B. and Kenley, R. (2004) 'The effectiveness of the bills of quantities in Australia', Journal of Construction Research, 5 (2), 291 - 309. 